\title{
Determination of oxalic acid and other organic acids in honey and in some anatomic structures of bees
}

\author{
María Jesús NoZAL ${ }^{\text {a*}}$, José Luis BernAL ${ }^{\mathrm{a}}$, Luis Antonio GóMEZ ${ }^{\mathrm{a}}$, \\ Mariano HIGES $^{\mathrm{b}}$, Aranzazu MEANA ${ }^{\mathrm{c}}$ \\ a Departamento de Química Analítica, Facultad de Ciencias, Universidad de Valladolid, 47005 Valladolid, Spain \\ b Centro Apícola Regional Junta de Comunidades de Castilla La Mancha, 19180 Marchamalo, Guadalajara, Spain \\ c Departamento de Patología Animal I (Sanidad Animal), Facultad de Veterinaria, Universidad Complutense, \\ Madrid, Spain
}

(Received 11 January 2002; revised 7 August 2002; accepted 7 October 2002)

\begin{abstract}
The use of two ion-exclusion columns coupled in series allows the liquid chromatographic determination of the oxalic acid content in honey and in some anatomic structures of bees, and avoids interference from other components of the matrix. To obtain a profile of organic acids, it is advisable to couple of four columns in series. The oxalic acid concentration in the rectum, Malpighian tubules, digestive tract and haemolymph is strongly influenced by the application mode (topical or oral). Results obtained demonstrate that in topical administration oxalic acid penetrates through the keratin.
\end{abstract}

ion exclusion chromatography / oxalic acid / organic acids / honey / honeybee

\section{INTRODUCTION}

Among the organic acids assayed to control Varroa destructor (Anderson and Trueman, 2000), oxalic acid has shown the greatest efficacy until now (Imdorf et al., 1997; Mutinelli et al., 1997, Nanetti and Stradi, 1997; Higes et al., 1998; Arculeo, 2000). This acid has recently been included as an active ingredient for varroosis treatment in the Regulation, EC 2377/90, ANEXE II, and also in the Articles belonging to Ecological Agriculture of the Regulation, EC 1804/99. This fact makes it a suitable acaricide to be developed as a veterinary drug in apiculture. This requires the demonstration of safety for the consumer of honey, for the environment and for the user, with certain specific requirements regarding efficacy and target animal safety.
Some long term toxic effects of oxalic acid on honey bee colonies have been reported (Higes et al., 1999). The elucidation of the mechanism of action and also the knowledge of the implied target organs are very important to establish the most adequate composition and dosage for veterinary drug use. Therefore, it is necessary to develop a method to determine the concentration of oxalic acid in honey and in different parts of honeybees after applying the drug.

We have not found any reference to the determination of this acid in anatomic structures or in the haemolymph of honey bees. Similarly, there have been few determinations of oxalic acid in honey, because the acid elutes in the chromatographic front or overlaps with the first eluting peaks (Cherchi et al., 1994; Blanco et al., 1996;

\footnotetext{
* Correspondence and reprints

E-mail: mjdnozal@qa.uva.es
} 
Nozal et al., 1998). As a result, oxalic acid is not usually considered in the acid profile of honey.

Taking these observations into account, we have tried to develop a method, using ionexclusion columns, first to determine only the presence of oxalic acid in several matrices, and second to obtain a profile of other organic acids, including oxalic. Moreover, due to the high sensitivity and simplicity of the method, we have applied it to determine trace amounts of oxalic acid in some anatomic structures (haemolymph, rectum, Malpighian tubules and digestive tracts) of honeybees, treated topically (thorax and abdomen) or orally with different oxalic acid solutions.

\section{MATERIALS AND METHODS}

\subsection{Reagents}

Analytical standard-grade acids (oxalic, d-glucuronic, citric, galacturonic, propionic, pyruvic, malic, citramalic, quinic, d-gluconic, lactic, formic, glutaric, fumaric, succinic and butyric acid) were obtained from Sigma Aldrich Química (Madrid, Spain). Water was purified by passage through a Compact Milli-RO and Milli-Q water system from Millipore (Bedford, MA, USA). Sulfuric acid, phosphoric acid and all other chemicals used were of analytical-reagent grade and supplied by Merck (Darmstad, Germany). All solutions used were filtered through a $0.45 \mu \mathrm{m}$ membrane filter from Millipore to remove any impurities.

\subsection{Equipment and conditions}

The chromatographic set-up consisted of a PV-1580 pump with degasser module, a LG-158004 gradient module and an AS-1555 autosampler for fifty samples with a variable injection loop of 5-100 $\mu$ l, all from Jasco Analitica Spain (Madrid, Spain). A UV-VIS Diode Array Detector UV6000, attached to a UV6000 LP Chromatography Data System from TSP Spectra System (San José, CA, USA), were also used to select adequate wavelength.

An ultrasonic bath, a vibromatic stirrer and a centrifuge (Selecta, Barcelona, Spain), a vortex mixer (Fisher Scientific, Pittsburgh, PA, USA), and a $5810 \mathrm{R}$ refrigerated centrifuge (Eppendorf, Hamburg, Germany) were also used.

The columns used were four IC-Pak ${ }^{\mathrm{R}}$ ionexclusion columns of $30 \times 0.78 \mathrm{~cm}$, with $7 \mu \mathrm{m}$,
50 A packing from Waters Corporation (Milford, MA,USA).

Columns temperature was maintained using a Peltier Column Thermostat A-2103 from Thermotechnic Products GmbH (Langenzersdorf, Austria).

The chromatographic separation of the acids was achieved by using water with $0.1 \% \quad(\mathrm{v} / \mathrm{v})$ phosphoric acid as mobile phase at a flow rate of 1 $\mathrm{mL} / \mathrm{min}$.

Samples were injected by means of the autosampler, always using a fixed volume of $10 \mu \mathrm{L}$, and detection at $210 \mathrm{~nm}$.

\subsection{Standard calibration}

Stock solutions of acids of $1 \mathrm{~g} / \mathrm{L}$ were always made in the mobile phase and stored at $4{ }^{\circ} \mathrm{C}$. Mixtures of different concentrations were made from those solutions.

Calibration graphs were obtained using 10 different concentrations of the mixed standard solutions. All samples were prepared and injected in triplicate.

\subsection{Sampling and treatments}

To check the applicability of the method, it was tested on 58 honey samples all collected in the same geographical area (Soria Province, Spain), and belonging to different botanical sources, which were confirmed by standard pollen analysis.

The method was also applied to trace analysis of oxalic acid in some anatomic structures of bees. For this purpose, groups of 10 adult bees were chosen, gassed with a current of carbon dioxide and dissected.

The treatments made were as follows:

(a) topical administration ( $3 \mu \mathrm{L}$ on thorax and $3 \mu \mathrm{L}$ on abdomen) of an aqueous solution of oxalic acid at $20 \%(\mathrm{w} / \mathrm{v})$

(b) topical administration ( $3 \mu \mathrm{L}$ on thorax and $3 \mu \mathrm{L}$ on abdomen) of an aqueous solution of oxalic acid at $10 \%(\mathrm{w} / \mathrm{v})$

(c) oral administration of a $2 \%$ solution of oxalic acid in an aqueous 50\% sucrose solution.

Prior to HPLC analysis, honey samples were subjected to a $1 \mathrm{~g}: 10 \mathrm{~mL}$ dilution, adding first $0.2 \mathrm{~mL}$ of $2 \mathrm{M}$ sulfuric acid and completing the volume with the aqueous solution of $0.1 \%$ in phosphoric acid.

Honeybee samples were obtained from 10 adult bees, which were placed in an eppendorf microvial, with $50 \mu \mathrm{L}$ of water, and kept in a refrigerator at $10^{\circ} \mathrm{C}$. Before their analysis, they were brought to room temperature. After centrifuging to $10000 \mathrm{~g}$ 


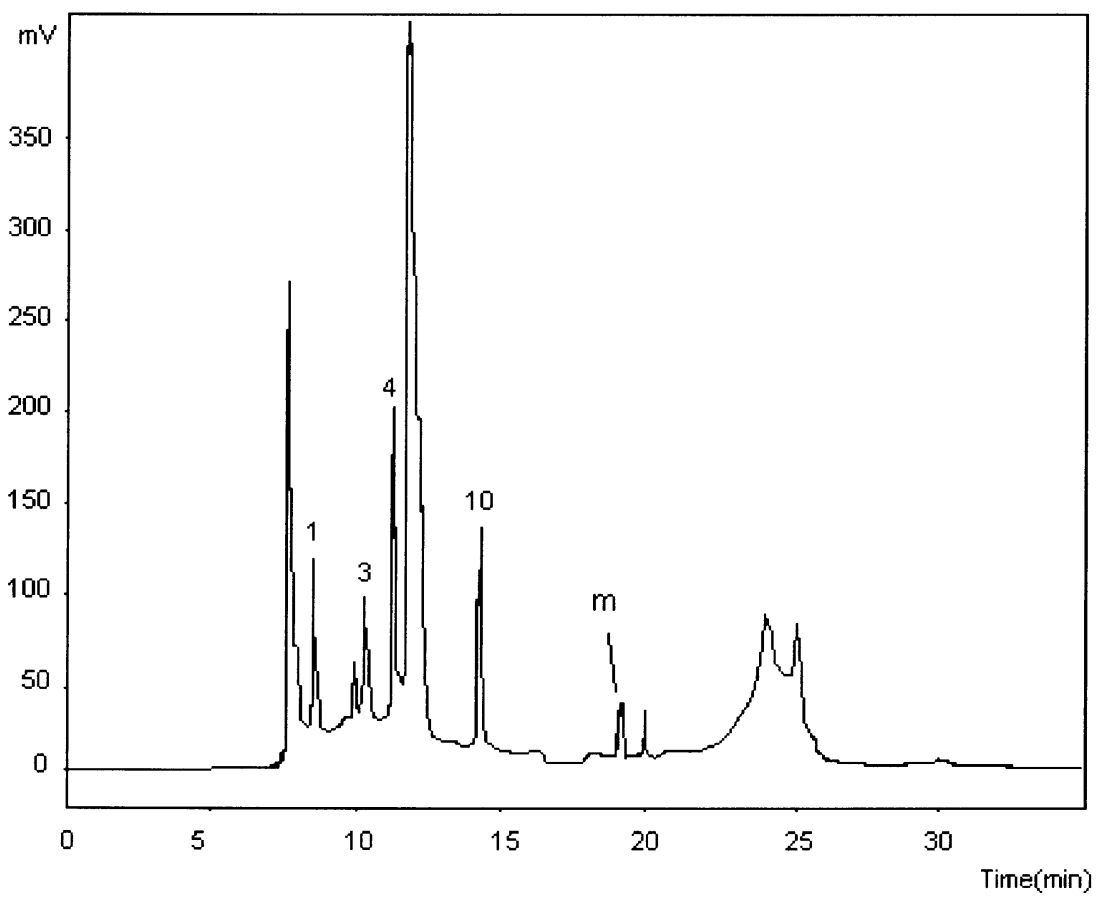

Figure 1. Chromatogram obtained from a multifloral honey sample using two columns coupled in series. $1=$ oxalic acid, $2=\mathrm{D}$-glucoronic acid, $3=$ citric acid, $4=$ galacturonic acid, $5=$ propionic acid, $6=$ pyruvic acid, $7=$ malic acid, $8=$ citramalic acid, $9=$ quinic acid, $10=$ D-gluconic acid, $11=$ lactic acid, $12=$ formic acid, 13 = glutaric acid, 14 = butyric acid, $\mathrm{m}=$ fumaric+succinic+malic acids.

and pouring them through a $0.45 \mu \mathrm{m}$ filter, aliquots of $10 \mu \mathrm{L}$ were injected in the chromatographic system.

\section{RESULTS AND DISCUSSION}

\subsection{Chromatographic conditions}

In order to maximize the resolution, different experimental parameters influencing the retention (stationary phase, mobile phase, temperature) were always optimized by varying one parameter at a time, and keeping all the others constant.

\subsubsection{Determination of oxalic acid}

Our intention was initially to find a method to determine the presence of oxalic acid. We therefore tried several columns and conditions, typically used to separate organic acids in different matrices. Several mobile phases, such as ammonium dihydrogen phosphate, sulfuric acid and phosphoric acid, at different concentrations and $\mathrm{pH}$ were tested, but a good separation was not obtained. Nevertheless, phosphoric acid showed the best results.

Finally we decided to try ion-exclusion columns and aqueous phosphoric acid as a mobile phase. The use of only one column did not allow a good separation of oxalic acid. This problem was addressed by coupling two similar columns in series, although the other acids considered in this study still eluted overlapped.

With both ion-exclusion columns in series, the influence of the concentration of phosphoric acid on the resolution was studied, varying it between $0.005 \%$ and a $0.2 \%$. The retention time for oxalic acid was not strongly influenced, whereas for the other acids the effect was important. Because of that, we selected a percentage of an $0.1 \%$, which avoided the overlapping with the oxalic acid peak. 
The 2 column coupling was thermostated from 20 to $60^{\circ} \mathrm{C}$, at intervals of $10{ }^{\circ} \mathrm{C}$, and a mobile phase consisting of $0.1 \%$ phosphoric acid was used. As expected, an increase in temperature caused a decrease in the retention times. Nevertheless, the temperature changes did not affect the resolution of oxalic acid. We finally selected $40{ }^{\circ} \mathrm{C}$ because, as it will be explained later, this temperature was the best option to separate the other acids.

A chromatogram from a multifloral honey sample obtained with this coupling is shown in Figure 1. As can be seen, oxalic acid is easily evaluated, although the other acids appear very overlapped. Fumaric, malic and succinic acids elute at the same retention time (peak m).

\subsubsection{Organic acids profile}

It is obvious that in the samples, there must be other acids together with oxalic, which had caused problems when using only one column. Their separation was also not achieved with two columns coupled in series. To obtain a better separation, we added consecutively one or two columns. From the results obtained, we recommend the use of four columns in series.

Studying the influence of the phosphoric acid concentration on solute retention, it was observed that concentrations higher or lower than $0.1 \%$ led to overlapping among several acids, so finally an $0.1 \%(\mathrm{v} / \mathrm{v})$ of phosphoric acid was selected.

In order to assess the effect of temperature on the separation, the columns were again thermostated from 20 to $60{ }^{\circ} \mathrm{C}$, at intervals of $10^{\circ} \mathrm{C}$, using an aqueous mobile phase containing a $0.1 \%(\mathrm{v} / \mathrm{v})$ of phosphoric acid. It could be observed that higher temperatures caused a decrease in the retention times, particularly for the most strongly retained compounds. A temperature of $40{ }^{\circ} \mathrm{C}$ was selected, because at this temperature most of the acids considered eluted individually.

Taking into account the results obtained above, an aqueous phase of $0.1 \%(\mathrm{v} / \mathrm{v})$ of phosphoric acid and a working temperature of $40{ }^{\circ} \mathrm{C}$ were selected. Under these conditions an overlapping (malic-fumaric-succinic, peak named $\mathrm{m}$ ) still appeared. A chromatogram of the same sample as in Figure 1, is shown in
Figure 2-a. As can be observed, the separation achieved is better.

Retention times were highly reproducible among chromatograms. The variation coefficients obtained for the mixture of 16 standards $(250 \mathrm{mg} / \mathrm{L}$ each) in six consecutive runs ranged from $2.25 \times 10^{-2}$ for pyruvic to $9.55 \times 10^{-2}$ for quinic.

The analytical characteristics of the proposed method are summarized in Table I.

The detection and determination limits were calculated experimentally as a signal-tonoise ratio of 3 and 10 , respectively.

\subsection{Application of the proposed method}

In Figure 2, some chromatograms obtained applying the procedure to some unifloral honey samples and a Malpighian tubule sample are shown. As can be observed, it is possible to determine the acids without interference from the matrix.

The results obtained in the study of the acid profile of some honey and honeydew samples are summarized in Table II. As can be seen, there are important differences among their origins and the concentration ranges are also of different amplitude. The samples with the highest acid content are those belonging to Calluna vulgaris, Erica sp. and honeydew. Dark honeys often have high acid contents.

The results obtained from analyzing several structures of honeybees after applying different treatments and sampling at different intervals are summarized in Table III. It can be observed that in topical administration, a maximum always appeared within the 4-6 hours after treatment. This means that oxalic acid passes through the keratin of the bee and reaches internal structures, which can explain the toxic effect reported. Oral administration gives the highest values for the oxalic acid, because although the dose is lower, the passage is more direct.

\section{CONCLUSIONS}

The use of four ion-exclusion columns coupled in series allows the analysis of the acids: d-glucuronic, citric, galacturonic, propionic, pyruvic, malic, citramalic, quinic, 

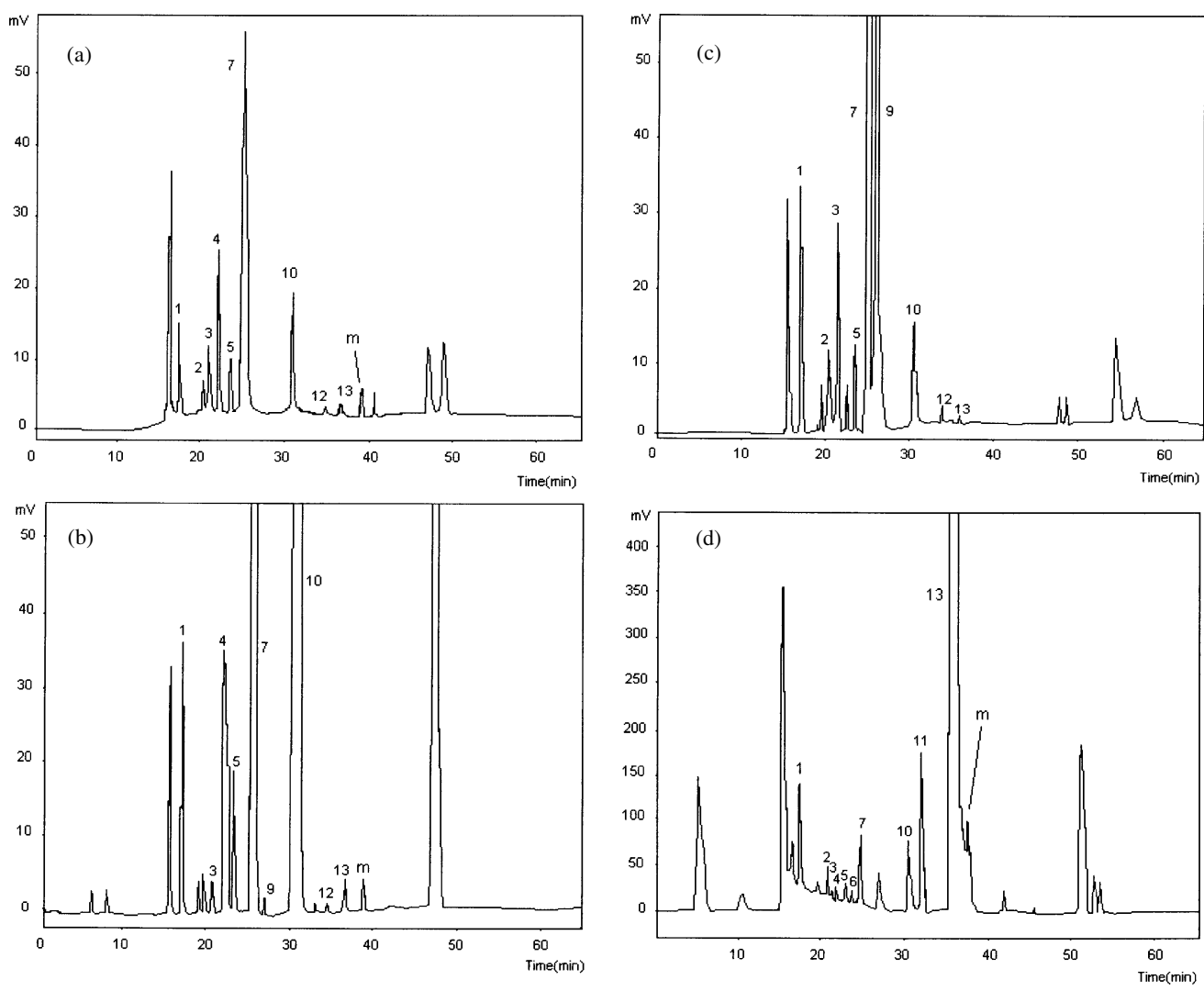

Figure 2. Chromatograms obtained using 4 columns coupled in series. (a) multifloral honey sample; (b) Calluna vulgaris honey; (c) Thymus vulgaris honey; (d) Malpighian tubules sample.

$1=$ oxalic acid, $2=$ D-glucoronic acid, $3=$ citric acid, $4=$ galacturonic acid, $5=$ propionic acid, $6=$ pyruvic acid, $7=$ malic acid, $8=$ citramalic acid, $9=$ quinic acid, $10=$ D-gluconic acid, $11=$ lactic acid, $12=$ formic acid, 13 = glutaric acid, 14 = butyric acid, $\mathrm{m}=$ fumaric + succinic + malic acids.

Table I. Some characteristics of the analytical method derived from the standard calibration data set.

\begin{tabular}{lccc}
\hline \multicolumn{1}{c}{ Acid } & Detection limit $(\mathrm{mg} / \mathrm{L})$ & Determination limit $(\mathrm{mg} / \mathrm{L})$ & Linearity range $(\mathrm{mg} / \mathrm{L})$ \\
\hline 1. Oxalic & 0.05 & 0.18 & $0.20-500$ \\
2. D-Glucuronic & 0.78 & 2.59 & $3.00-500$ \\
3. Citric & 0.16 & 0.56 & $0.60-500$ \\
4. Galacturonic & 1.70 & 5.70 & $6.00-500$ \\
5. Propionic & 1.33 & 4.44 & $5.00-500$ \\
6. Pyruvic & 0.07 & 0.26 & $0.30-500$ \\
7. Malic & 0.67 & 2.23 & $2.50-500$ \\
8. Citramalic & 1.91 & 6.36 & $7.50-500$ \\
9. Quinic & 21.75 & 72.5 & $75.00-500$ \\
10. D-Gluconic & 1.52 & 5.06 & $5.25-500$ \\
11. Lactic & 0.51 & 1.70 & $2.00-500$ \\
12. Formic & 1.17 & 3.91 & $4.00-500$ \\
13. Glutaric & 1.07 & 3.58 & $4.00-500$ \\
14. Butyric & 1.66 & 5.54 & $6.00-500$ \\
\hline
\end{tabular}


Table II. Mean average and concentration ranges, found for the oxalic acid content in the honey samples analyzed.

\begin{tabular}{lcc}
\hline Botanical origin & Concentration range $\left(\mathrm{mg} / \mathrm{kg}_{\text {honey }}\right)$ & Average oxalic acid $\left(\mathrm{mg} / \mathrm{kg}_{\text {honey }}\right)$ \\
\hline Ling( Calluna vulgaris) & $104-160$ & 133 \\
Heather (Erica sp) & $85.5-168$ & 128 \\
Honeydew ( Quercus ilex) & $52.3-73.1$ & 63.9 \\
Thyme (Thymus vulgaris) & $41.6-82.9$ & 60.3 \\
Multifloral & $14.5-49.8$ & 28.8 \\
Lavender (Lavandula latifolia) & $11.3-46.4$ & 24.9 \\
French Lavender (Lavandula stoechas) & $20.9-22.4$ & 21.6 \\
Rosemary (Rosmarinus officinalis) & $15.3-23.2$ & 21.0 \\
\hline
\end{tabular}

Table III. Oxalic acid content in some anatomic structures of honeybees after different treatments.

\begin{tabular}{|c|c|c|c|c|c|c|}
\hline Sample type & $\begin{array}{c}\text { Sampling time } \\
\text { Treatment (a) }\end{array}$ & $\begin{array}{c}\text { Oxalic acid } \\
(\mu \mathrm{g} / \text { honeybee })\end{array}$ & $\begin{array}{l}\text { Sampling time } \\
\text { Treatment (b) }\end{array}$ & $\begin{array}{c}\text { Oxalic acid } \\
(\mu \mathrm{g} / \text { honeybee })\end{array}$ & $\begin{array}{l}\text { Sampling time } \\
\text { Treatment (c) }\end{array}$ & $\begin{array}{c}\text { Oxalic acid } \\
(\mu \mathrm{g} / \text { honeybee })\end{array}$ \\
\hline \multirow[t]{5}{*}{ Haemolymph } & $O h$ & 0.06 & $2 h$ & 0.06 & $24 h$ & 0.06 \\
\hline & $2 h$ & 0.13 & $4 h$ & 0.21 & $48 h$ & 0.19 \\
\hline & $4 h$ & 0.23 & $6 h$ & 0.08 & $72 h$ & 0.08 \\
\hline & $6 h$ & 0.65 & $8 h$ & 0.06 & & \\
\hline & $8 h$ & 1.29 & $24 h$ & 0.09 & & \\
\hline \multirow[t]{5}{*}{ Rectum } & $O h$ & 0.08 & $2 h$ & 0.12 & $24 h$ & 0.10 \\
\hline & $2 h$ & 0.15 & $4 h$ & 0.11 & $48 h$ & 1.03 \\
\hline & $4 h$ & 0.18 & $6 h$ & 0.11 & $72 h$ & 0.43 \\
\hline & $6 h$ & 0.35 & $8 h$ & 0.12 & & \\
\hline & $8 h$ & 0.24 & $24 h$ & 0.11 & & \\
\hline \multirow[t]{5}{*}{$\begin{array}{l}\text { Malpighian } \\
\text { tubule }\end{array}$} & $O h$ & 0.09 & $2 h$ & 0.11 & $24 h$ & 0.23 \\
\hline & $2 h$ & 0.16 & $4 h$ & 0.10 & $48 h$ & 0.56 \\
\hline & $4 h$ & 0.22 & $6 h$ & 0.07 & $72 h$ & 0.85 \\
\hline & $6 h$ & 0.17 & $8 h$ & 0.12 & & \\
\hline & $8 h$ & 0.27 & $24 h$ & 0.10 & & \\
\hline \multirow[t]{5}{*}{$\begin{array}{l}\text { Digestive } \\
\text { tract }\end{array}$} & $O h$ & 0.16 & $2 h$ & 0.14 & $24 h$ & 0.34 \\
\hline & $2 h$ & 0.18 & $4 h$ & 0.17 & $48 h$ & 1.82 \\
\hline & $4 h$ & 0.53 & $6 h$ & 0.11 & $72 h$ & 0.33 \\
\hline & $6 h$ & 0.99 & $8 h$ & 0.09 & & \\
\hline & $8 h$ & 0.54 & $24 h$ & 0.13 & & \\
\hline
\end{tabular}

(a) Topical administration of oxalic acid at $20 \%$.

(b) Topical administration of oxalic acid at $10 \%$.

(c) Oral administration of $2 \%$ oxalic acid in aqueous $50 \%$ sucrose solution.

d-gluconic, lactic, formic, glutaric, fumaric, succinic and butyric, in honey and anatomic parts of honeybees. To evaluate only the oxalic acid, two columns coupled in series is enough. In both cases the mobile phase is an aqueous solution of $0.1 \%(\mathrm{v} / \mathrm{v})$ phosphoric acid.

Oxalic acid is found in honey in various proportions according to the botanical source considered. The highest values $(>100 \mathrm{mg} / \mathrm{kg}$ ) 
are found in Calluna vulgaris and Erica sp.pl. and in honeydew samples ( $>60 \mathrm{mg} / \mathrm{kg}$ ).

The concentrations of oxalic acid in the rectum, Malpighian tubules, digestive tracts and haemolymph of bees depend on the mode of application (topical or oral).

After topical administration, there is an interval of time in which the oxalic concentration in internal organs of the bee increases. This demonstrates that, when hives are treated against Varroa destructor, oxalic acid penetrates through bee keratin and can produce the toxic effect.

\section{ACKNOWLEDGEMENT}

Financial support of this Project (API98-002) by MAPA-INIA (Spain) is gratefully acknowledged.

\section{Résumé - Détermination de l'acide oxalique et d'autres acides organiques dans le miel et certaines structures anatomiques de l'Abeille domestique. L'acide oxalique semble être un agent efficace pour traiter les ruches contre l'infestation par l'acarien Varroa destructor (Imdorf et al., 1997; Higes et al., 1998; Arculeo, 2000). Des craintes ont récemment surgi concernant un éventuel effet toxique à long terme pour les abeilles (Higes et al., 1999). Pour connaître l'éventuel effet négatif, il est nécessaire de tester si certaines doses peuvent agir sur des structures anatomiques internes des abeilles. Le but de ce travail est de mettre au point une méthodologie analytique qui permet de déterminer l'acide oxalique résiduel dans certaines parties de l'Abeille, en essayant d'établir la répartition de l'acide dans les tissus et ses éventuels effets toxiques.}

Pour déterminer des traces de l'acide, nous avons utilisé un procédé basé sur la chromatographie liquide haute performance avec quatre colonnes à exclusion d'ions montées en série. La phase mobile est un mélange d'eau et d'acide phosphorique à $0,1 \%(\mathrm{v} / \mathrm{v})$ détectant à $210 \mathrm{~nm}$. Cela permet de séparer l'acide oxalique et aussi les acides d-glucuronique, citrique, galacturonique, propionique, pyruvique, malique, citramalique, quinique, d-gluconique, lactique, formique, glutarique, fumarique, succinique et butyrique. Le procédé peut donc être utilisé pour obtenir des informations concernant d'autres acides organiques présents dans les échantillons (Fig. 2).

Pour analyser le miel et le miellat, les échantillons ont été dilués $(10 \mathrm{~mL}$ pour $1 \mathrm{~g})$ en ajoutant d'abord $0,2 \mathrm{~mL}$ d'acide sulfurique à $2 \mathrm{M}$ et en complétant le volume avec une solution aqueuse d'acide phosphorique à $0,1 \%$. Les échantillons de miel placés dans un flacon Eppendorf ont été centrifugés à $10000 \mathrm{~g}$, après addition de $50 \mu \mathrm{L}$ d'eau déionisée, puis passés à travers un filtre de 0,45 microns. Les limites de détection obtenus avec ce procédé variaient entre $0,05 \mathrm{mg} / \mathrm{L}$ pour l'acide oxalique et $21,75 \mathrm{mg} / \mathrm{L}$ pour l'acide quinique, avec une limite supérieure de linéarité proche de $500 \mathrm{mg} / \mathrm{L}$, ce qui permet de déterminer les acides dans une large gamme de concentrations.

Le procédé a été utilisé pour obtenir la teneur en acide oxalique d'échantillons de miel de diverses sources botaniques (Tab. II) et aussi pour déterminer les quantités résiduelles d'acide oxalique dans l'hémolymphe, le rectum, les tubes de Malpighi et le tube digestif des abeilles. L'acide oxalique a été administré aux abeilles par voie orale et topique et les échantillons ont été prélevés à intervalles (Tab. III). L'administration topique aboutit toujours à un intervalle de temps au cours duquel la concentration en acide oxalique dans les organes internes des abeilles est plus forte. Ceci montre que l'acide oxalique traverse la kératine et qu'il pourrait contribuer à l'effet toxique.

acide oxalique / acide organique / chromatographie par exclusion d'ions / Apis mellifera / miel / résidu

Zusammenfassung - Bestimmung von Oxalsäure und anderen freien Säuren in Honig und einigen anatomischen Strukturen von Bienen. Oxalsäure scheint ein wirksames Mittel bei der Behandlung von Bienenvölkern gegen den Befall mit Varroa destructor zu sein (Imdorf et al., 1997; Higes et al., 1998; Arculeo, 2000). Kürzlich sind Zweifel über eine mögliche Langzeitschädigung der Bienen aufgekommen (Higes et al., 1999). Um diese mögliche negative Auswirkung zu untersuchen ist es notwendig zu testen, ob die Dosis einen Effekt auf innere anatomische Strukturen hat. Ziel der Untersuchung war, analytische Methoden aufzuzeigen mit denen Oxalsäurereste in einigen Organen der Bienen nachgewiesen werden können, um das Verteilungsmuster im Körper und seine mögliche negative Auswirkung zu verstehen.

Um Spuren der Säure quantitativ bestimmen zu können, wurde eine Aufbereitung gewählt, die auf HPLC beruht unter Nutzung von 4 aufeinander folgenden Säulen mit Ionenausschluss. Die mobile Phase besteht aus Wasser mit $0.1 \%$ (v/v) Phosphorsäure und eine Überprüfung bei $210 \mathrm{~nm}$. So kann eine Auftrennung von Oxalsäure und auch von den Säuren d-Glucuron-, Zitronen-, Galacturon-, Propion-, Brenztrauben-, Apfel-, cisApfel-, China, d-Glucon-, Milch-, Ameisen-, Glutar-, Fumar-, Bernstein- und Buttersäure 
erfolgen. Deshalb kann diese Methodik auch für Untersuchungen über andere organische Säuren in Gewebe und anderen Proben genutzt werden (Abb. 2). Zur Analyse von Honig und Honigtau wurden Proben von $1 \mathrm{~g}$ in $10 \mathrm{~mL}$ Lösungsmittel überführt, indem zunächst $0,2 \mathrm{~mL}$ 2 M Schwefelsäure zugfügt wurden und dann auf das Volumen mit einer wässerigen $0,1 \%$ Phosphorsäure aufgefüllt wurden. Die Bienenproben wurden in ein Eppendorf Gefäß getan, dann $50 \mu \mathrm{L}$ deionisiertes Wasser zugefügt und bei $10000 \mathrm{~g}$ zentrifugiert. Danach wurde alles durch einen $0.45 \mu \mathrm{m}$ Filter gegeben. Die Nachweisgrenzen, die mit dieser Methode erreicht wurden, schwankten zwischen $0.05 \mathrm{mg} / \mathrm{L}$ für Oxalsäure $21.75 \mathrm{mg} / \mathrm{L}$ für Chinasäure, mit einer oberen linearen Grenze von etwa $500 \mathrm{mg} / \mathrm{L}$. Das erlaubte eine große Bandbreite der Konzentrationen zu bestimmen.

Diese Methode wurde für die Bestimmung von Oxalsäure in Honigproben verschiedener botanischer Herkunft (Tab. II) und auch zur Bestimmung von Rückständen der Oxalsäure in Haemolymphe, Rectum, Malpighischen Gefäßen und im Verdauungstrakt der Bienen angewandt. Oxalsäure wurde Bienen oral oder topical zugeführt und in bestimmten Zeitintervallen wurden Proben (Tab. III) genommen. Nach topicaler Anwendung gibt es immer ein Zeitfenster, in dem die Konzentration an Oxalsäure in allen Geweben erhöht ist. Dies zeigt, dass Oxalsäure durch das Keratin dringt und auf diese Weise könnte der toxische Effekt entstehen.

\section{Ionenausschluss Chromatographie / Oxalsäure / organische Säuren / Honig / Honigbienen}

\section{REFERENCES}

Anderson D.L., Trueman J.W.H. (2000) Varroa jacobsoni (Acari: Varroidae) is more than one species, Exp. Appl. Acarol. 24, 165-189.

Arculeo P. (2000) Acido oxálico: Experiencia en el Sur de Italia, Vida Apícola 102, 44-48.

Blanco D., Quintanilla M.E., Mangas J.J., Gutierrez M.D. (1996) Determination of organic acids in apple juice by capillary liquid chromatography, J. Liq. Chromatogr. 19, 2615-2621.

Cherchi A., Spanedda L., Tuberoso C., Cabras P. (1994) Solid-Phase Extraction and High-Perfomance Liquid-Chromatographic Determination of organic-acids in Honey, J. Chromatogr. A 669, 59-64.

Higes M., Sanz A., Llorente J., Suarez M., Pérez J.L. (1998) Influencia del método de aplicación en la eficacia acaricida del ácido oxálico frente a Varroa jacobsoni Oud., Med. Vet. 11, 592-595.

Higes M., Meana A., Suarez M., Llorente J. (1999) Negative long-term effects on bee colonies treated with oxalic acid against Varroa jacobsoni Oud., Apidologie 30, 289-292.

Imdorf A., Charrière J.D., Bachofen B. (1997) De l'utilisation de l'acide oxalique comme varroacide, Apiacta 32, 89-91.

Mutinelli F., Baggio A., Capolongo F., Piro R., Prandlin L., Biasson I. (1997) A scientific note on oxalic acid by topical application for the control of varroosis, Apidologie 28, 461-467.

Nanetti A., Stradi G. (1997) Varroasi: trattamento chimico con acido ossalico in scirppo zuccherino, L'Ape Nostra Amica, 5, 6-14.

Nozal M.J., Bernal J.L., Marinero P., Diego J.C., Frechilla J.I., Higes M., Llorente J. (1998) Highperformance liquid-chromatographic determination of organic acids in honeys from different botanical origin, J. Liq. Chromatogr. Rel. Technol. 21,3197 . 